\title{
$P$ gene mutations in patients with oculocutaneous albinism and findings suggestive of Hermansky-Pudlak syndrome
}

\author{
N A Garrison, Z Yi, O Cohen-Barak, M Huizing, L M Hartnell, W A Gahl, M H Brilliant
}

J Med Genet 2004;41:e86 (http://www.jmedgenet.com/cgi/content/full/41/6/e86). doi: 10.1136/jmg.2003.014902

$\mathrm{O}$ culocutaneous albinism (OCA) is a genetically heterogeneous disorder characterised by abnormally low amounts of melanin in the eyes, skin, and hair. In addition to hypopigmentation of the skin and eyes, OCA patients have ocular manifestations including nystagmus, foveal hypoplasia with reduced visual acuity, and strabismus. ${ }^{1}$ Several subtypes of OCA exist. OCA2, the most common subtype, results from mutations in the $P$ gene. $^{23}$ OCA2 patients have a broad range of phenotypes, with minimal to moderate pigmentation of the hair, skin, and iris that may darken with age. ${ }^{1}$ OCAl is the second most common type and is caused by mutations in the tyrosinase gene, TYR.$^{45}$ The lack of functional tyrosinase results in the complete absence of pigmentation in hair and skin. Rarer forms of OCA include OCA3, also known as "rufous/red albinism" and associated with mutations in the TYRPI gene, and OCA4, associated with mutations in the MATP gene. Finally, some genetic defects in intracellular vesicle formation and trafficking have OCA as a major clinical component. ${ }^{89}$ For example, Chediak-Higashi syndrome (CHS) is characterised by giant intracellular granules, an often fatal diathesis to infection, and variable degrees of hypopigmentation. ${ }^{10}$ Hermansky-Pudlak syndrome (HPS) involves OCA as part of a constellation of findings that include platelet storage pool deficiency and, in some patients, accumulation of ceroid pigment, pulmonary fibrosis, and/or granulomatous colitis. ${ }^{11}$ The sine qua non of HPS is absence of platelet dense bodies on whole mount electron microscopy. ${ }^{12}$ CHS and HPS can have overlapping phenotypes. For example, HPS-2, associated with mutations in the $\beta 3 \mathrm{~A}$ subunit of adaptor complex- $3,{ }^{13}$ manifests with neutropenia and childhood infections reminiscent of CHS. ${ }^{14}{ }^{15}$

Because of our interest in hypopigmentation and disorders of intracellular vesicles, we investigated all patients having OCA plus a history of bleeding, frequent infections, or some other HPS-related symptoms. We screened eight such individuals with clinical manifestations suggestive of HPS. Five of the eight had definitive molecular evidence for OCA2. We now describe those patients and their $P$ gene mutations.

\section{METHODS}

\section{Patients}

All patients had OCA plus some suggestion of HPS or an HPSrelated syndrome. Each was enrolled in a protocol approved by an NIH institutional review board and written informed consent was obtained from each patient or their parents.

\section{Electron microscopy}

Platelets were examined for dense bodies by whole mount electron microscopy as previously described. ${ }^{12}$

\section{Mutation analyses}

DNA was extracted from whole blood using standard techniques. HPS-causing genes were screened using several different methods. HPSI was investigated using Northern

\section{Key points}

- Eight patients with oculocutaneous albinism (OCA) and other features suggestive of Hermansky-Pudlak syndrome were evaluated for mutations in HPS-associated genes and the OCA2-associated $P$ gene. Since the clinical presentations were suggestive of HermanskyPudlak syndrome (HPS), we initially screened for mutations in HPS-causing genes. No HPS1, AP3B1A, or HPS3 mutations were detected. Next, we screened for mutations in the $P$ gene associated with OCA2, the most common form of OCA.

- Three of the eight patients exhibited previously described mutations in the $P$ gene in the homozygous or compound heterozygous states, making the diagnosis of OCA2. In two other patients, a single mutant allele of the $P$ gene was detected. The identification of $P$ gene mutations in HPS-like patients with manifestations suggesting HPS indicates that OCA2, and perhaps other types of OCA, should be considered in such individuals.

- Differentiating among the various types of albinism remains a difficult task, since many patients carrying the diagnosis of OCA (or even ocular albinism) actually have HPS, while patients thought to have HPS or an HPS-like syndrome may have another basis for their hypopigmentation, demonstrating the importance of molecular diagnosis.

blotting and direct sequencing, AP3B1A using Western blot analysis with an antibody to the $\beta 3 \mathrm{~A}$ subunit of adaptor complex-3, and $H P S 3^{16}$ by Northern blotting. For $P$ gene mutation screening, primers covering all coding sequences and intron-exon boundaries were used to amplify the patients' genomic DNA, as described elsewhere. ${ }^{17}$ PCR products were purified by the QIAquick Purification Kit and sequenced using an ABI 377 sequencer. Screening of the $P$ gene $2.7 \mathrm{~kb}$ deletion was performed as previously described. ${ }^{3}$ The sequences were analysed with Sequencher 3.1.1 software. When necessary, clonal analysis was applied to determine heterozygosity using a TA cloning Kit (Invitrogen).

\section{RESULTS}

\section{Molecular findings}

Initially, we used the criterion of absence or presence of dense bodies in platelets to categorise all our patients with clinical manifestations suggestive of HPS. Eight patients had dense bodies in their platelets and were subjected to further

Abbreviations: CHS, Chediak-Higashi syndrome; HPS, HermanskyPudlak syndrome; OCA, oculocutaneous albinism 
molecular analyses. No HPS1, AP3B1A, or HPS3 mutations were identified in any of the eight patients in the initial molecular analyses using direct sequencing, Northern blotting, or Western blotting. Next, since OCA2 is the most common type of albinism, we screened for mutations in the OCA2 associated gene, the $P$ gene. Five of the eight patients had previously reported $P$ gene mutations. ${ }^{38-20}$ Both $P$ allele mutations were identified in three patients, while only one mutation was found in the other two patients (table 1).

\section{Clinical and laboratory data}

In addition to having dense bodies in their platelets, the five OCA2 patients also lacked giant inclusions in their leukocytes, eliminating any close resemblance to CHS. The patients ranged in age from 1 to 32 years and were of various ethnicities (table 1). The severity of hypopigmentation and ophthalmic findings varied considerably. Skin and hair colour ranged from completely white to brown (fig l) and visual acuities were between 20/300 and 20/50. No OCA2 patient had any significant history of bleeding or granulomatous colitis. Only patient no 5 had pulmonary insufficiency; her forced vital capacity was $61 \%$ of predicted, total lung capacity $71 \%$ of predicted, and diffusing capacity for carbon monoxide $81 \%$ of predicted. She complained of dyspnea, but was pregnant at the time and, therefore, a chest CT scan was not performed. All five patients had varying histories of increased infections, including frequent episodes of otitis, sinusitis, pneumonias, and urinary tract infections (table 1).

\section{DISCUSSION}

Differentiating among the various types of albinism remains a difficult task. For example, many patients carrying the diagnosis of OCA or even ocular albinism ${ }^{12}{ }^{21}$ actually have HPS. Conversely, patients thought to have HPS or an HPSlike syndrome may have another basis for their hypopigmentation. In fact, here we describe five patients referred to an HPS investigational protocol who actually had mutations in the $P$ gene, giving them the diagnosis of OCA2. In these five cases, the findings suggestive of HPS-like disorders included a high frequency of infections, and indications of a bleeding diathesis (bruising, idiopathic thrombocytopenic purpura, history of transfusion) or pulmonary insufficiency. Because OCA2 is associated solely with hypopigmentation, these additional findings proved to be incidental and not related to the primary cause of albinism in these patients.

Currently, the absence or presence of platelet dense bodies on whole mount electron microscopy makes or excludes the diagnosis of HPS. In contrast to the definitive studies of a whole mount examination, however, results of standard transmission electron microscopy of platelets can be ambiguous, since electron-dense organelles such as lysosomes and $\alpha$-granules can be mistaken for dense bodies. Moreover,
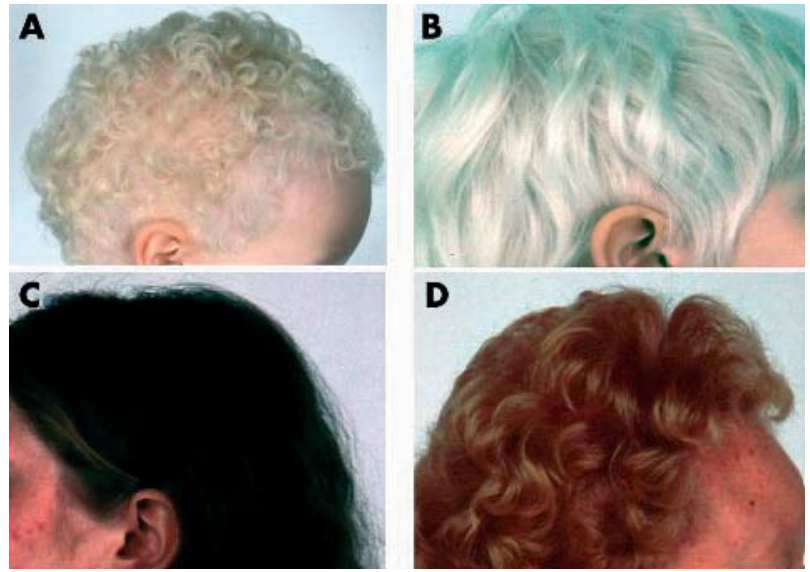

Figure 1 Hair and skin of patients no 1 (A), no 2 (B), no $3(\mathbf{C})$, and no 5 (D).

reports indicate that HPS patients can have reduced numbers of dense bodies rather than a complete absence of dense bodies, ${ }^{22}{ }^{23}$ although these studies lacked molecular verification of the diagnosis of HPS, and the dense body analysis was performed by transmission electron microscopy. Therefore, even though the eight patients described here had dense bodies in their platelets when examined by electron microscopy, we still subjected these patients to further molecular screening for HPS mutations. There is a possibility that Western blotting to detect AP3BI gene mutations and Northern blotting to detect HPS3 gene mutations in this study may have missed some types of mutations. However, the identification of mutations in the $P$ gene in these patients suggests that they likely do not carry mutations in $A P 3 B 1$ or HPS 3, since the coincidence of mutations in one of these HPS-causing genes and the $P$ gene is highly unlikely. Our laboratories continue to search for HPS variants who have molecularly verified mutations in HPS-causing genes, along with dense bodies which are decreased in number but not completely absent. To date, no such patients have been identified.

Our findings also point to the phenotypic heterogeneity of OCA2. Patient \#3 is heterozygous for the mutation, 1327G $>$ A (V443I), which is consistent with $P$ gene albinism. At the age of 2 months, she was diagnosed with albinism and had nystagmus, white hair, sun sensitivity, and a visual acuity of 20/50. Some of these signs decreased with age, as patient \#3 currently has medium brown hair and pigmented skin. We have not discovered this patient's second $P$ gene mutation. However, we do not always detect mutations in both alleles; the undetected allele could be located in a promoter region, an intron, or some other area not routinely sequenced.

Table 1 Clinical and molecular findings in OCA-2 patients

\begin{tabular}{|c|c|c|c|c|c|c|c|}
\hline $\mathrm{Pt} /$ age/sex* & Ethnicity† & Visual acuity & Bleeding & Gltt & Infections ${ }^{* *}$ & Pulmonary & Mutations \\
\hline $1 / 1 / M$ & AAm/Ger-Iri-PR & $20 / 300$ & None & None & $\begin{array}{l}\text { Otitis (7), sinusitis (2), mastitis, } \\
\text { impetigo }\end{array}$ & NA & $\begin{array}{l}2.7 \mathrm{~kb} \text { del }(\mathrm{ex} 7) / \\
1327 \mathrm{G}>\mathrm{A}\end{array}$ \\
\hline $2 / 2 / F$ & Fre-Can/Fre-Can & NA & Bruising & Cramp & Otitis (4), urinary tract infection & Asthma & $2207 \mathrm{C}>\mathrm{T} / \mathrm{NA}$ \\
\hline $3 / 22 / F$ & Ger/Eng & $20 / 50$ & None & None & $\begin{array}{l}\text { Otitis frequent, pneumonias } \\
\text { (5), sinusitis, yeast }\end{array}$ & $\begin{array}{l}\text { Asthma, normal } \\
\text { CT }\end{array}$ & $1327 \mathrm{G}>\mathrm{A} / \mathrm{NA}$ \\
\hline $4 / 29 / F$ & Ash/Ash & $20 / 100$ & ITP§ & IBS & Infectious mononucleosis & None & $79 \mathrm{C}>\mathrm{A} / 79 \mathrm{C}>\mathrm{A}$ \\
\hline $5 / 32 / \mathrm{F}$ & AAm/Dut & $20 / 250$ & $\begin{array}{l}\text { Transfusion } \\
\text { after surgery }\end{array}$ & None & $\begin{array}{l}\text { Otitis frequent, pneumonias } \\
\text { (3), urinary tract infection }\end{array}$ & Asthma, dyspnea & $\begin{array}{l}2.7 \mathrm{~kb} \text { del(ex7)/ } \\
\text { 819CTGG > GGTC }\end{array}$ \\
\hline
\end{tabular}

*Pt, patient number; †AAm, African American; Ger, German; Iri, Irish; PR, Puerto Rican; Fre-Can, French Canadian; Eng, English; Ash, Ashkenazi Jewish; Dut, Dutch; $\ddagger N A$, not available; §ITP, idiopathic thrombocytopenic purpura; ††Gl, gastrointestinal; $\uparrow \mid \mathrm{BS}$, irritable bowel syndrome; ${ }^{* *}$ numbers in the parentheses indicate the numbers of infections. 
A complete characterisation of the various subtypes of HPS requires examination of individuals who have OCA along with other HPS-related symptoms. Many of these subjects will prove to have common types of albinism such as OCA2, but this should not mitigate against an aggressive pursuit of the entire spectrum of disorders involving hypopigmentation, platelet storage pool deficiency, an infectious diathesis, pulmonary fibrosis, and/or granulomatous colitis.

\section{Authors' affiliations}

N A Garrison* $¥$, Z Yi , O Cohen-Barak, M H Brilliant, Department of Pediatrics, College of Medicine, University of Arizona, Tucson, AZ 85724, USA

Z Yi, M H Brilliant, Graduate Interdisciplinary Program in Genetics, University of Arizona, Tucson, AZ 85724, USA

M Huizing, W A Gahl, Section on Human Biochemical Genetics, Heritable Disorders Branch, National Institute of Child Health and Human Development, and Medical Genetics Branch, National Human Genome Research Institute, NIH, Bethesda, MD 20892, USA L M Hartnell, Cell Biology and Metabolism Branch, NICHD, NIH, Bethesda, MD 20892, USA

This work was supported by National Institutes of Health grant AR4596 (to MHB). NAG was supported by MARC program Grant T34 GM08718.

Conflict of interest: none declared.

${ }^{*}$ Current address: Department of Genetics, Stanford University School of Medicine, Stanford, CA 94305, USA

$\ddagger$ These authors contributed equally to this work.

Correspondence to: $\mathrm{M} \mathrm{H}$ Brilliant, Department of Pediatrics, PO Box 245073, University of Arizona College of Medicine, 1501 N. Campbell Avenue, Tucson, AZ 85724, USA; mhb@peds.arizona.edu

Received 6 November 2003

Accepted for publication 2 December 2003

\section{REFERENCES}

1 King RA. Genetic hypomelanoses: disorders characterized by generalized hypomelanoses. In: Norlund JJ, Boissy RE, Hearing VJ, King RA, Ortonne J-P, eds. The pigmentary system: physiology and pathophysiology. New York: Oxford University Press, 1998:553-75.

2 Rinchik EM, Bultman SJ, Horsthemke B, Lee ST, Strunk KM, Spritz RA Avidano KM, Jong MTC, Nicholls RD. A gene for the mouse pink-eyed dilution locus and for human type II oculocutaneous albinism. Nature 1993;361:72-6.

3 Durham-Pierre D, Gardner JM, Nakatsu Y, King RA, Francke U, Ching A Aquaron R, de Marmol V, Brilliant MH. African origin of an intragenic deletion of the human $\mathrm{P}$ gene in tyrosinase positive oculocutaneous albinism. Nat Genet 1994;7:176-9.

4 Tomita Y, Takeda A, Okinaga S, Tagami H, Shibahara S. Human oculocutaneous albinism caused by single base insertion in the tyrosinase gene. Biochem Biophys Res Commun 1989;164:990-6.
5 Oetting WS, Fryer JP, King RA. Mutations of the human tyrosinase gene associated with tyrosinase related oculocutaneous albinism (OCA1). Hum Mutat 1998;12:433-4.

6 Boissy RE, Zhao H, Oetting WS, Austin LM, Wildenberg SC, Boissy YL, Zhao Y, Sturm RA, Hearing VJ, King RA, Nordlund JJ. Mutation in and lack of expression of tyrosinase-related protein-1 (TRP-1) in melanocytes from an individual with brown oculocutaneous albinism: a new subtype of albinism classified as "OCA3". Am J Hum Genet 1996;58:1145-56.

7 Newton JM, Cohen-Barak O, Hagiwara N, Gardner JM, Davisson MT, King RA, Brilliant MH. Mutations in the human orthologue of the mouse underwhite (uw) gene underlie a new form of oculocutaneous albinism, OCA4. Am J Hum Genet 2001;69:981-8.

8 Huizing M, Anikster Y, Gahl WA. Hermansky-Pudlak syndrome and ChediakHigashi syndrome: disorders of vesicle formation and trafficking. Thromb Haemost 2001;86:233-45.

9 Huizing M, Scher CD, Strovel E, Fitzpatrick DL, Hartnell L, Anikster Y, Gahl WA. Nonsense mutations in ADTB3A cause complete deficiency of the beta3A subunit of adaptor complex-3 and severe Hermansky-Pudlak syndrome type 2. Pediatr Res 2002;51:150-8.

10 Introne W, Boissy RE, Gahl WA. Clinical, molecular, and cell biological aspects of Chediak-Higashi syndrome. Mol Genet Metab 1999:68:283-303.

11 Huizing M, Anikster Y, Gahl WA. Hermansky-Pudlak syndrome and related disorders of organelle formation. Traffic 2000;1:823-35.

12 Witkop CJ, Krumwiede M, Sedano H, White JG. Reliability of absent platelet dense bodies as a diagnostic criterion for Hermansky-Pudlak syndrome. Am J Hematol 1987; 26:305-11.

13 Oh J, Bailin T, Fukai K, Feng GH, Ho L, Mao J-I, Frenk E, Tamura N, Spritz RZ. Positional cloning of a gene for Hermansky-Pudlak syndrome, a disorder of cytoplasmic organelles. Nat Genet 1996;14:300-6.

14 Shotelersuk V, Dell'Angelica EC, Hartnell L, Bonifacino JS, Gahl WA. A new variant of Hermansky-Pudlak syndrome due to mutations in a gene responsible for vesicle formation. Am J Med 2000;108:423-7.

15 Huizing M, Boissy RE, Gahl WA. Hermansky-Pudlak syndrome: vesicle formation from yeast to man. Pigment Cell Res 2002;15:405-19.

16 Anikster Y, Huizing M, White J, Bale S, Gahl WA, Toro J. Mutation of a new gene causes a unique form of Hermansky-Pudlak syndrome in a genetic isolate of central Puerto Rico. Nat Genet 2001;28:376-80.

17 Lee ST, Nicholls RD, Jong MTC, Fukai K, Spritz RA. Organization and sequence of the human $\mathrm{P}$ gene and identification of a new family of transport proteins. Genomics 1995;26:354-63.

18 Spritz RA, Lee ST, Fukai K, Brondum-Nielsen K, Chitayat D, Lipson MH, Musarella MA, Rosenmann A, Weleber RG. Novel mutations of the P gene in type II oculocutaneous albinism. Hum Mutat 1997;10:175-7.

19 Lee ST, Nicholls RD, Schnur RE, Guida LC, Lu-Kuo J, Spinner NB, Zackai EH, Spritz RA. Diverse mutations of the $\mathrm{P}$ gene among African-Americans with type II (tyrosinase-positive) oculocutaneous albinism (OCA2). Hum Mol Genet 1994; 3:2047-51.

20 Lee ST, Nicholls RD, Bundey S, Laxova R, Musarella M, Spritz RA. Mutations of the $P$ gene in oculocutaneous albinism, ocular albinism, and Prader-Willi syndrome plus albinism. N Engl J Med 1994;330:529-34.

21 Huizing $M$, Anikster $Y$, Fitzpatrick $D L$, Jeong $A B, D^{\prime}$ Souza $M$, Rausche $M$, Kaiser-Kupfer MI, White JG, Gahl WA. Hermansky-Pudlak syndrome type 3 in Ashkenazi Jews and other non-Puerto Rican patients with hypopigmentation and platelet storage pool deficiency. Am J Hum Genet 2001;69:1022-32.

22 Harrison C, Khair K, Baxter B, Russell-Eggitt I, Hann I, Liesner R. HermanskyPudlak syndrome: infrequent bleeding and first report of Turkish and Pakistani kindreds. Arch Dis Child 2002;86:297-301.

23 Russell-Eggit IM, Thompson DA, Khair K, Leisner R, Hann IM. HermanskyPudlak syndrome presenting with subdural haematoma and retinal haemorrhages in infancy. JR Soc Med 2000;93:591-2. 